\title{
ВИВЧЕННЯ ВПЛИВУ ДЕЗІНФЕКТАНТІВ НА ОСНОВІ ХІМІЧНИХ РЕЧОВИН НА ШКАРАЛУПУ ЯЄЦЬ СІЛЬСЬКОГОСПОДАРСЬКОЇ ПТИЦІ
}

\author{
Петренко Ганна Олександрівна \\ аспірант \\ Сумський національний аграрний університет \\ ORCID: 0000-0002-3328-640X \\ E-meil:anyutapetrenko@gmail.com
}

Бордунова Ольга Георгієвна доктор сільськогосподарських наук, професор Сумський національний аграрний університет ORCID: 0000-0002-7120-1040

E-meil:bordunova.olga59@gmail.com

В роботі представлені результати вивчення дії дезінфректантів, основою яких є хімічні речовини, на структуру та властивості шкаралупи яєць сільськогосподарської птиці. Розглянуті дезінфекуючі властивості та вплив на шкаралупу та шкаралупні оболонки яєць сільськогосподарської птиці препаратів, що створені на основі альдегідовмісних речовин, сполук на основі перекису водню та речовин, що мають в основі надоцтову кислоту. Використання дезінфрікуючих речовин, які не впливають на якість шкаралупи інкубаційних яєць та позитивно діють на розвиток ембріонів сільськогосподарської птиці є актуальним питанням у птахівництві. В роботі використовували інкубаційні яйця курей леггорн білий. Для експериментів формували вісім груп по 144 яєщь в кожній. Перед закладкою на інкубацію яйця обробляли розчинами речовин та препаратів: формальдегідом, глютаральдегідом, метацидом, препаратами Virkon - S (KRKA, Cловенія), CID 20 з додаванням надоцтової кислоти (HOK), VIROCID з HOK, CID - 20, HOK та рослинні екстракти, VIROCID, HOK ma рослинні екстракти. Зразки шкаралупи аналізували за допомогою растрової електронної мікроскопії на приладі PEMMA102 відразу після висихання розчинів та після вилуплення курчат. Обробка яєць сільськогосподарської птиці дезінфрікуючими речовинами є однією з головних вимог інкубації. Проте використання дезінфектантів, що мають відмінні бактерицидні та фунгіцидні властивості, не завжди призводять до бажаного результату. Зокрема препарати, що створені на основі хімічних речовин, таких як альдегідовмісткі сполуки, знижують захисну дію кутикули та мають канцерогенні властивості щодо персоналу птахофрабрик. Препарати на основі пероксидів мають токсичну дію на ембріони, що розвиваються, та деструктивну активність щодо біокерамічного шару шкаралупи. Для пом'якшення негативного впливу препаратів, до складу яких входять дані речовини, рекомендовано додавати рослинні екстракти

Ключові слова: технологія, породи, інкубація, дезінфіккючі речовини, шкаралупа

DOI: https://doi.org/10.32845/bsnau.Ivst.2021.4.20

Однією з найважливіших умов при підготовці яєць сільськогосподарської птиці до інкубації є їх дезінфекція, що в свою чергу передбачає застосування різних технік обробки з використанням речовин різних хімічних груп.

Обробка хімічними препаратами інкубаційних яєць птиці передбачає застосування речовин, яким притаманна сильна бактерицидна, бактеріостатична і фунгіцидна активність. До хімічних засобів для дезінфекції відносяться: луги, кислоти, окислювачі, хлормістячі й альдегідвмісткі препарати, а також антибіотики $[10,11,12,13]$.

Однак, дослідники які займаються птахівництвом в країнах Західної Європи, Америки, Ізраїлю та інших країнах відмовляються від цих препаратів, тому що велика кількість із них мають підвищену токсичність стосовно ембріонів, що розвиваються, а також виражену канцерогенну й алергенну дію на персонал інкубаторіїв $[1,6]$.

Деякі препарати збільшують проникність пор яєць для агентів інфекцій, а інші ущільнюють поверхневий захисний шар шкаралупи, що призводить до погіршення надходження газів в середину яйця. Ці процеси мають патологічний вплив під час розвитку ембріонів птиці, і особливо в другий період інкубації, коли ембріони, що розвиваються, мають збільшену потребу в надходженні свіжого повітря і вологи [2,3].

Тому на разі актуальним питанням у птахівництві $€$

якість шкаралупи інкубаційних яєць та використання дезінфікуючих речовин, які не впливають на зазначені вище показники та позитивно діють на розвиток ембріонів сільськогосподарської птиці [4].

Виходячи 3 вище сказаного, метою даного дослідження було вивчення впливу на шкаралупу яєць сільськогосподарської птиці різних дезінфектантів, основою яких $€$ хімічні речовини.

Матеріали та методи дослідження. В роботі використовували інкубаційні яйця курей (леггорн білий; 15 тиждень яйцекладки), що були отримані від курей-несучок, яких утримували згідно з нормами щодо годівлі та утримання.

Для експериментів формували вісім груп по 144 яєць в кожній. Перед закладкою на інкубацію групи яєць обробляли розчинами речовин, а також модифікованими препаратами: 1) фумігація формальдегідом; 2) розчином глютаральдегіда; 3)розчином метациду; 4) розчином дезінфектанту Virkon - S (KRKA, Словенія); 5) розчином препарату CID - 20 3 додаванням надоцтової кислоти (HOK); 6) VIROCID та HOK; 7) розчином CID - 20, НОК та рослинні екстракти; 8) розчином VIROCID, HOK та рослинні екстракти.

Після висихання розчинів на поверхні оброблених яєць брали зразки з середньої частини шкаралупи розміром 3-6 мм² і готували проби для електронної мікроскопії. Зразки аналізували за допомогою растрової електронної мікроскопії 
на приладі РЕММА-102. Після вилуплення курчат відбирали шкаралупу і знову досліджували растровою електронною мікроскопією.

Результати досліджень. За результатами проведеної роботи було вивчено дію різних дезінфікуючих препаратів на структуру та властивості шкаралупи яєць.

Деякі з дезінфікуючих речовин, наприклад формаль-

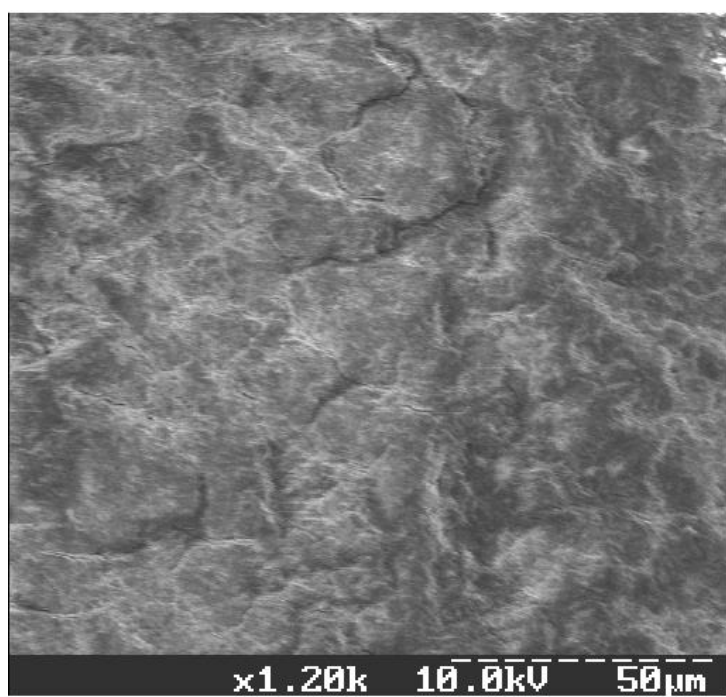

дегід, в умовах підвищеної вологості коагулює поверхневий шар надшкаралупної оболонки, а інші - зв'язують білкові компоненти кутикули яйця і тим самим інгібують її захисні властивості (глютаральдегід).

На рисунках 1 - 3 представлені мікросротографрії шкаралупи курячого яйця, оброблені перед інкубацією парами формальдегіду (рис. 1) та глютаральдегідом (рис. 2).

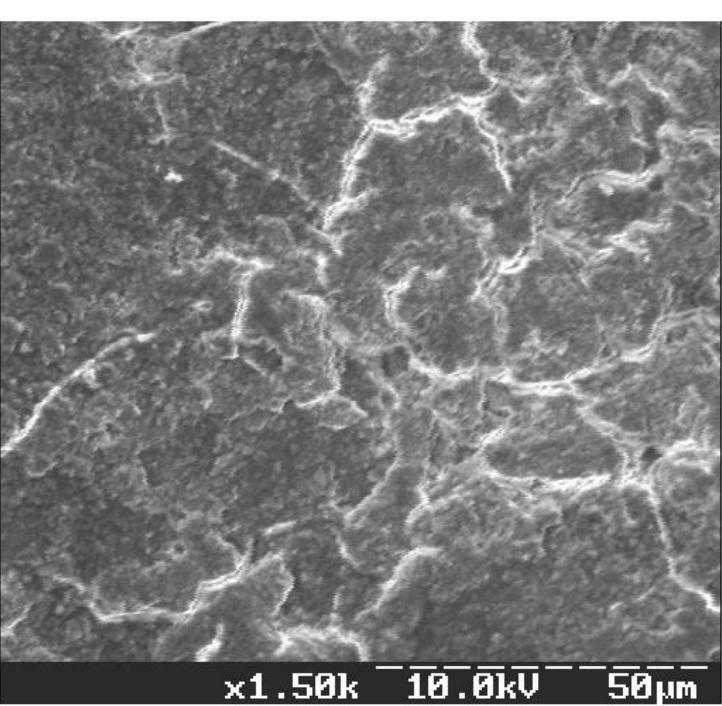

Рис 1. Електронні мікрофотографії зовнішньої поверхні курячого яйця, обробленого формальдегідом (х 1200 , х 1500$)$.
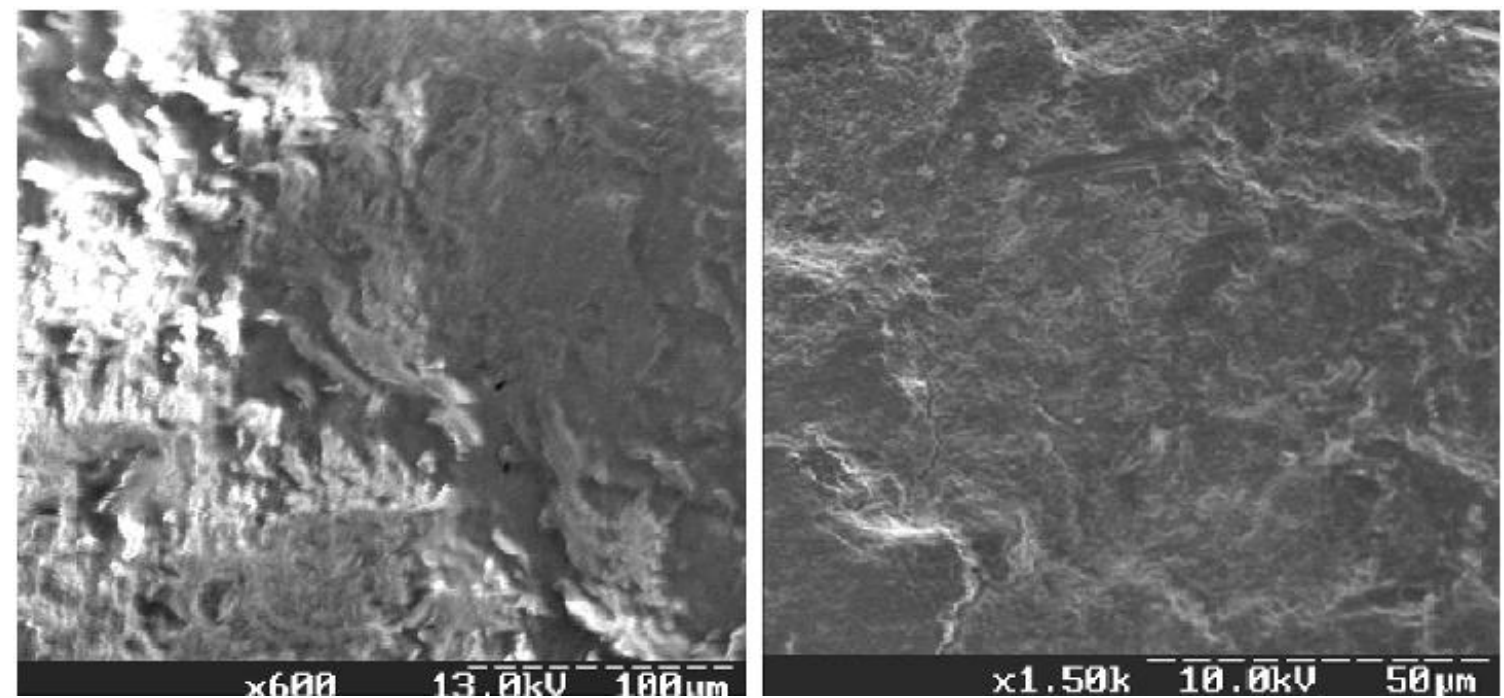

Рис 2. Електронні мікрофротографії зовнішньої поверхні курячого яйця, обробленого глютаральдегідом (х 600, х 1500$)$.

Використання метациду в якості дезінфікуючого засобу інкубаційних яєць також негативно впливає на зовнішню поверхню шкаралупи курячих яєць. При нанесенні на шкаралупу він утворює газонепроникну плівку різної товщи-

ни, утруднює при цьому проникнення повітря і вологи до ембріона (рис. 3). Метацид рекомендується використовувати не в чистому вигляді, а в препаративній формі з іншими речовинами.
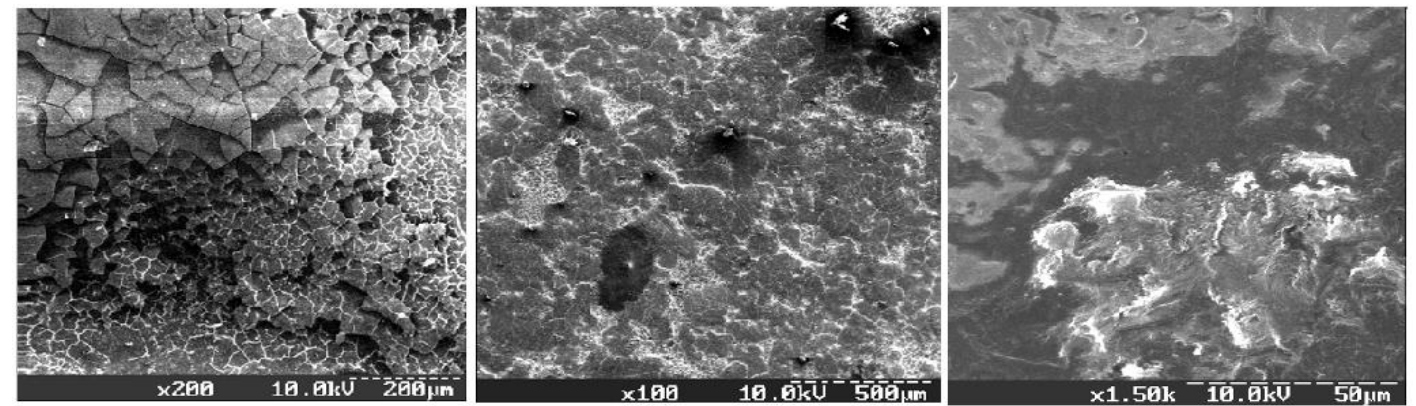

Рис. 3. Електронні мікрофротографії зовнішньої поверхні курячого яйця, обробленого метацидом (х 200; x100, x 1500 ). 
Дезінфектанти, що мають в основі пероксидні сполуки (зокрема, перекису водню $\left(\mathrm{H}_{2} \mathrm{O}_{2}\right)$ широко застосовуються для дезінфекції та стерилізації птахівничих приміщень. Перекису водню характерні такі важливі властивості, як відсутність запаху речовини, швидкий розпад у навколишньому середовищі на нетоксичні продукти, не викликає алергічну реакцію у персоналу.

Проте препарати, що містять в складі перекис водню, досить не стійкі сполуки, у порівнянні з іншими дезінфікуючими препаратами, мають низький рівень бактерицидної активності, при потраплянні на шкіру можуть викликати подразнення.

Підвищити активність перекису водню та твердих перекисних сполук: пероксигідрату карбаміду (гідроперит), пероксикарбонату натрію (персоль), пероксиборату натрію - дозволяє внесення до препарату активаторів (ацетилсаліцилової кислоти, йодиду калію, фториду калію).

Бактерицидний ефект дезінфектантів, які містять в основі пероксидні сполуки, спричинений свого роду аутолітичним «вибухом», що відбувається внаслідок реакцій перекисного окислення жирів. Дана реакція обумовлює вибірковий механізм бактерицидної дії з компонентами лізису, за рахунок руйнування відповідних структурних елементів клітинної стінки, що $€$ досить перспективним при використанні даних препаратів [7, 8, 9].

Препарат у твердій формі вдалося отримати внаслідок поєднання $\mathrm{H}_{2} \mathrm{O}_{2}$ i фрториду калія - пероксигідратфрториду калію. Сполука отримала назву «Ниток».

Дезінфікуючі речовини з більш активними та поліпшеними фізико-хімічними властивостями утворилися внаслідок поєднання сполук на основі перекису водню та четвертинного амонію (ЧАС). Так були створені препарати : Грилен, ПВК, Перамін, Пемос-1, Virkon - S тощо.

Словенські дезінфектанти Virkon та Virkon - S (Virkon(r), «КРКА») є збалансованими поєднаннями пероксидних сполук, поверхнево-активних речовин, органічних кислот та неорганічних бусерних систем. Основним компонентом цих препаратів $є 50 \%$ персульфат калію [5].

На рис. 4 - 6 представлені мікрофотографії шкаралупи курячого яйця, обробленого перед інкубацією препаратом Virkon - S (KRKA, Словенія).

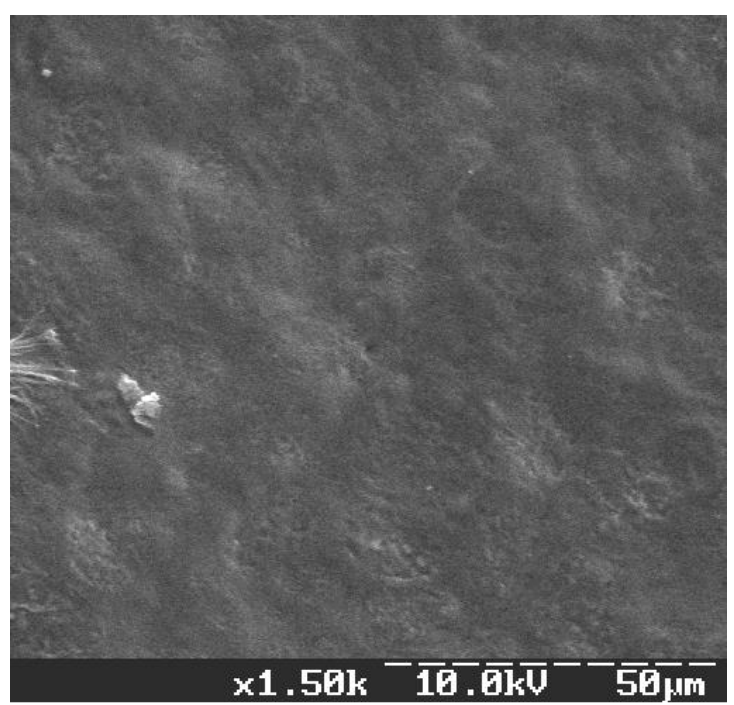

Рис. 4. Електронна мікрофотографрія зовнішньої поверхні шкаралупи курячого яйця, обробленої дезінфікуючим препаратом Virkon - S (KRKA, Словенія) (x 1500).

Дезінфектант Virkon - S - препарат з широким спектром дії щодо патогенних мікроорганізмів: бактерій, вірусів, грибів. Він $€$ помірно небезпечною сполукою за рівнем токсичності. В концентраціях, що рекомендуються до використання, не здійснює подразнення шкіри, але дещо може подразнити слизові оболонки, не проявляє алергенної та сенсибілізуючої реакції у персоналу. Робочі розчини препарату проявляють слабку корозивну активність щодо обладнання, але практично не псують матеріали оброблених поверхонь.

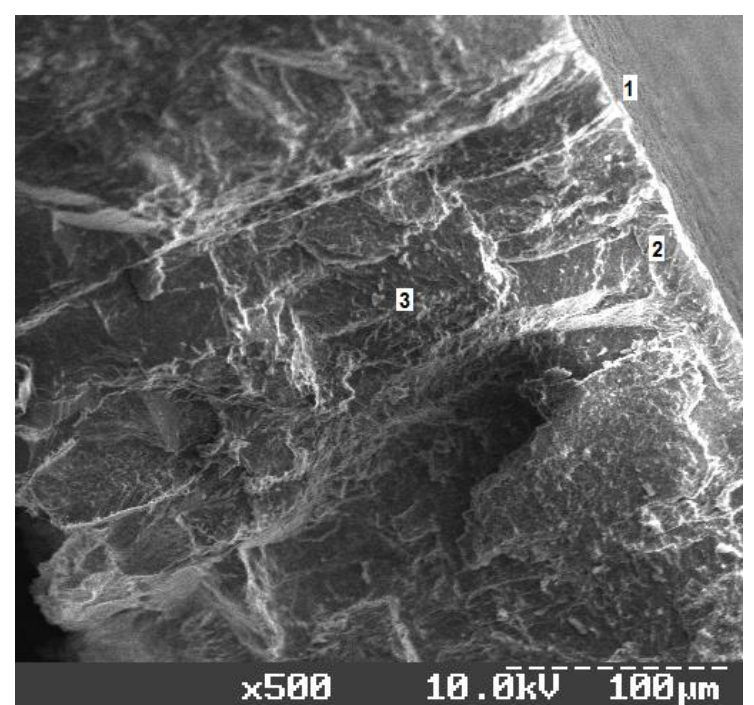

Рис. 5. Електронна мікрофотографія шкаралупи курячого яйця (скол), обробленого дезінфікуючим препаратом Virkon - S: 1 - зовнішня поверхня шкаралупи

(кутикула), оброблена препаратом; 2 - кристалічний вертикальний шар; 3 - палісадний шар (х 500).

Протимікробна активність робочих розчинів препарату зберігається протягом 5 діб.

Virkon - S застосовується для проведення профілактичної дезінфекції. Препарат рекомендований для оброблення виробничих приміщень та обладнання птахофабрик, тваринницьких господарств, ветеринарних клінік та лабораторій. Також використовується при ветеринарних станціях та вимушеній дезінфекції, під час бактеріальних (виключення туберкульоз) та вірусних інфекцій. 

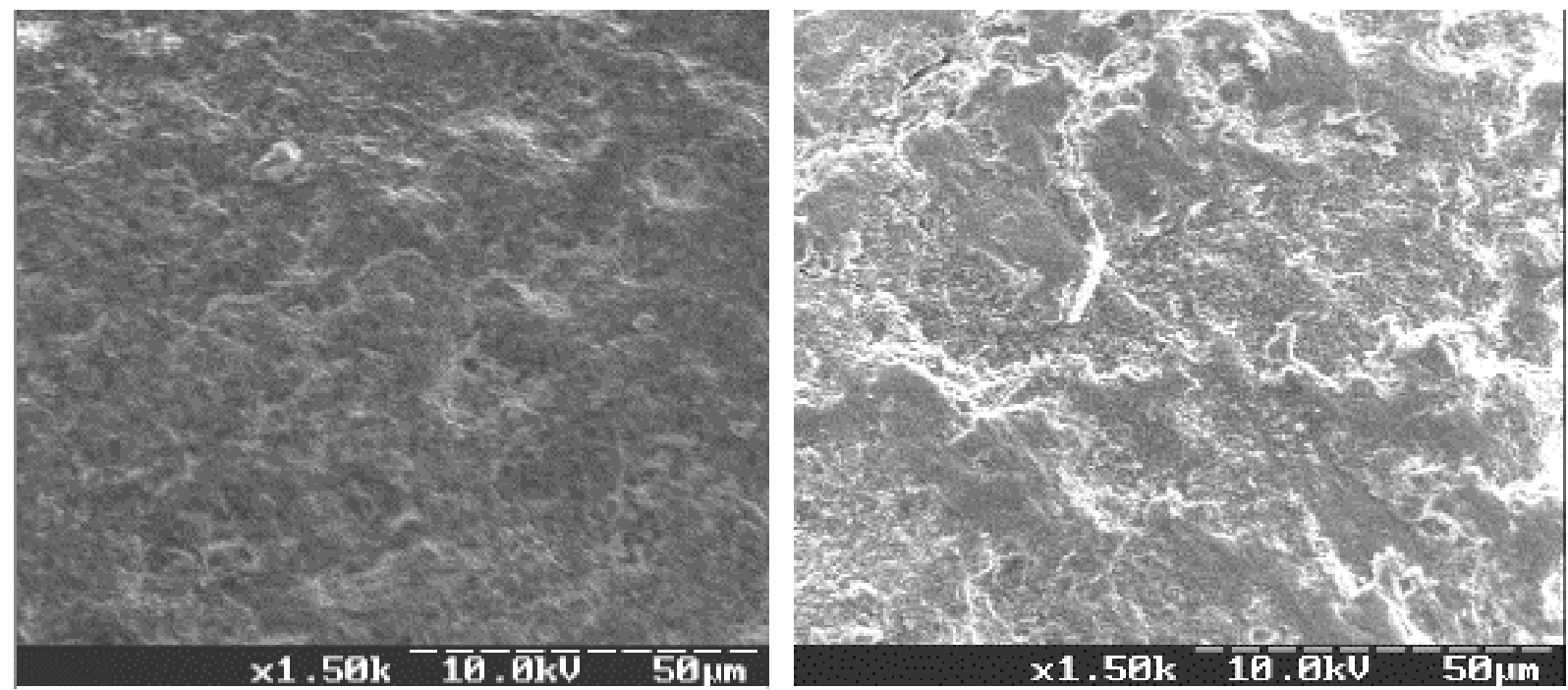

Рис. 6. Електронні мікрофотограффії зовнішньої поверхні курячого яйця, обробленого перед інкубацією препаратом Virkon - S. Зразки шкаралупи відібрані після вилуплення курчати. (х 1500$)$

Досконалою біоцидною речовиною, що відома не один десяток років $є$ надоцтова кислота (НОК).

Препарати: «АКВАдез-НУК-15», «АКВАдез-НУК 5» (ООО «АКВА-КЕМИКАЛ», С.-Пб., РФ), РЗ -оксонія® актив (ЭКОЛАБ), DIVOSANAKTIV, Неосептал - PE (Др. Вайгерт), "Кріодез", що містять у своєму складі НОК є максимально ефективними та екологічно безпечними дезінфектантами $[14,16]$.

Ці новітні препарати є оптимізованими, чотирикомпонентними стабілізованими сполуками води, перекису водню, оцтової і надоцтової кислот. На сьогодні успіху досягли спроби поєднання різних речовин з біоцидною дією з надоцтовою кислотою, а саме зі сполуками четвертинного амонію [15].

Надоцтова кислота є основним компонентом всіх стабілізованих препаративних форм. Молекули НОК є до- сить сильним окислювачем. При взаємодії з патогенними мікроорганізми, молекули надоцтової кислоти діють як зовні, так і в середині організму, руйнуючи мембрани, а зокрема білки і ліпіди, що є їх сладовими компонентами. Даний механізм дії забезпечує швидку загибель будь яких мікроорганізмів, зокрема бактерій, вірусів, та спор. НОК належить до невеликого кола дезінфектантів, яким притаманна здатність одночасно впливати на аеробну і анаеробну мікрофрлору. При використанні дизінфікуючих препаратів на основі надоцтової кислоти не спостерігається поява резистентних штамів мікроорганізмів.

В складі препаратів пероксидний компонент - НОК розрихлює плівку, сфрормовану базовими складовими ЧАС, i робить її проникною для газів та вологи, просочує неорганічний кальцитний матрикс, забезпечуючи надійну санацію останнього від патогенної мікрофолори (рис. 7).

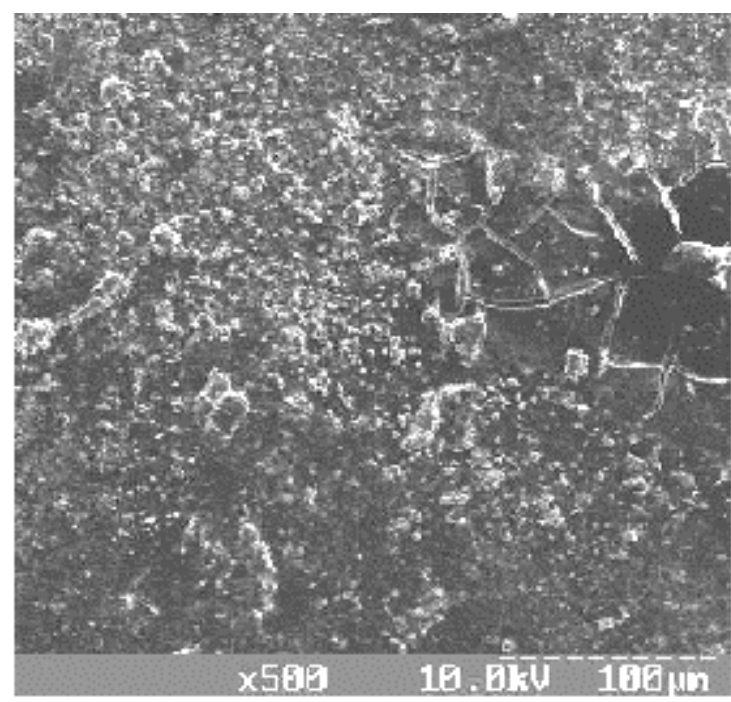

A

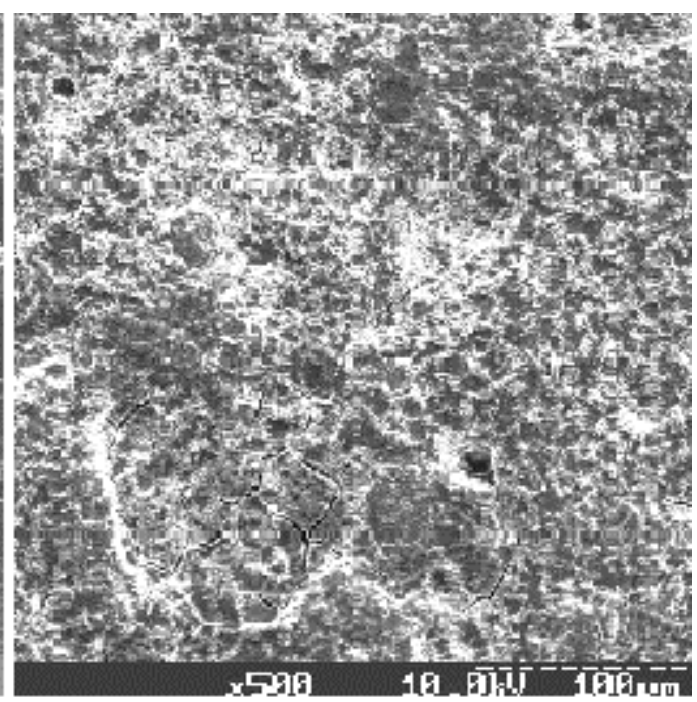

Б

Рис. 7. Електронна мікрофотограффія зовнішньої поверхні шкаралупи курячого яйця, обробленого перед інкубацією сумішшю препарату : A - CID - 20 та HOK (x 500); Б - VIROCID та HOK (х 500).

Рослинний екстракт (РЕ) завдяки сполукам, що містяться у ньому, має протирадикальні властивості і знижує

деструктивну активність надоцтової кислоти щодо біокерамічного шару шкаралупи (рис. 8). 


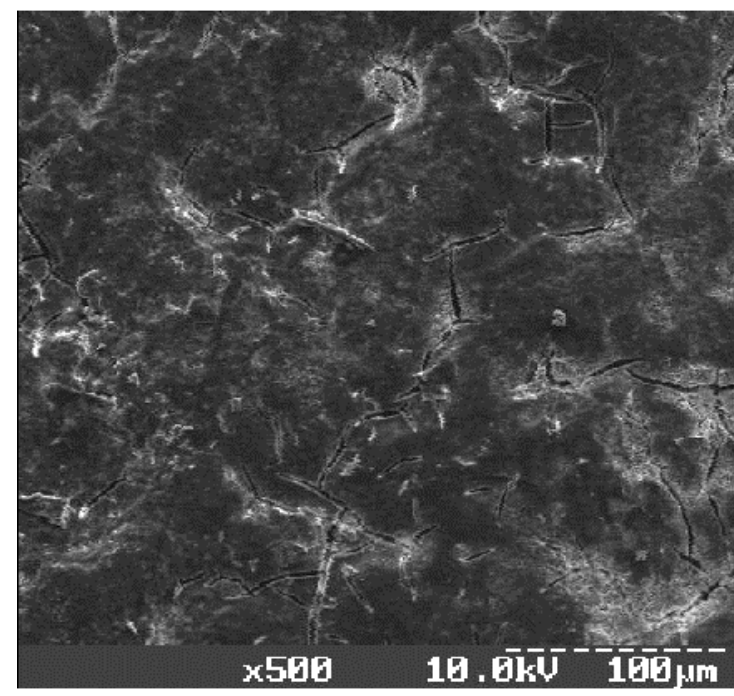

A

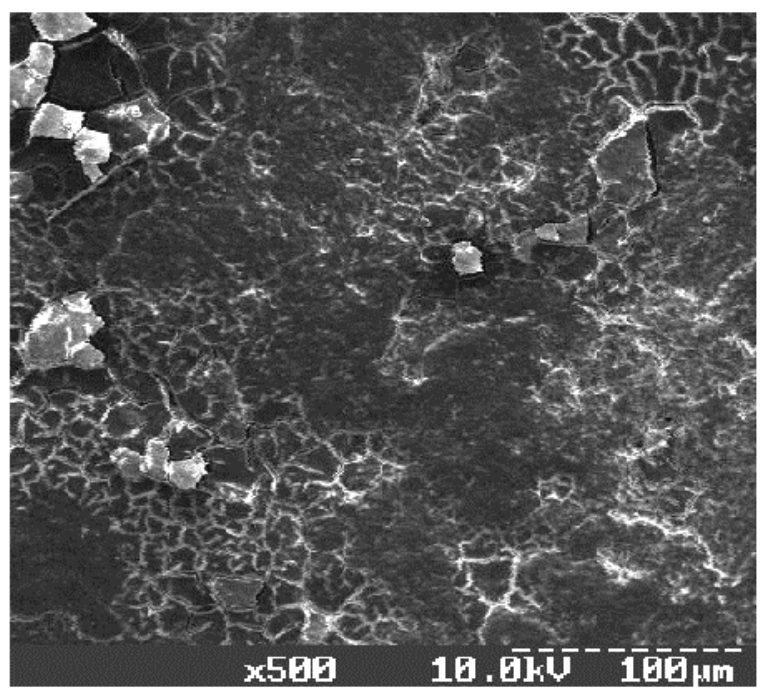

5

Рис. 8. Електронні мікрофоотографії зовнішньої поверхні шкаралупи курячого яйця, обробленого перед інкубацією сумішшю препарату: A - CID - 20, HOK та рослинних екстрактів (х 500); 5 - VIROCID, HOK та рослинних екстрактів

(зразок шкаралупи відібраний після вилуплення курчати) (х 500).

Для пом'якшення дії на шкаралупу яєць надоцтової кислоти в препарат додавали сумарний рослинний екстракт (PE), який складався з рівних об'ємів екстрактів, отриманих з таких біологічно-активних компонентів: горіху волоського Juglansregia; елеутерококу колючого Eleuterococcussenticosus Maxim; ехіноцеї пурпурової, Echinaceapurpurea Moench.; звіробою звичайного Hypericumperforatum L.; золотого кореню - Rhodiolarosea L.; лимоннику китайського - Schisandrachinensis (Turcz.) Baill.; нагідок лікарських (календули) - Calendula officinalis L.; обліпихи крушиноподібної - Hippophaërhamnoides L.; полину гіркого - Artemisiaabsinthium L.; ромашки лікарської Matricariarecutita (Chamomilla) L.; сосни лісової Pinussilvestris L.; тополі чорної - Populusnigra L.; хмелю звичайного - Humuluslupulus L.; ялівця звичайного Juniperuscommunis L.; екстракту виноградних кісточок (10 \% водний розчин). PE $€$ біологічно - активним компонентом, що

\section{підвищує виводимість та збереженість птиці.}

Висновки. Обробка яєць сільськогосподарської птиці дезінфікуючими речовинами $є$ однією з головних вимог інкубації. Проте використання дезіндектантів, що мають відмінні бактерицидні та фунгіцидні властивості, не завжди призводять до бажаного результату. Зокрема препарати, що створені на основі хімічних речовин, таких як альдегідовмісткі сполуки, знижують захисну дію кутикули та мають канцерогенні властивості щодо персоналу птахофабрик. Препарати на основі пероксидів мають токсичну дію на ембріони, що розвиваються, та деструктивну активність щодо біокерамічного шару шкаралупи. Для пом'якшення негативного впливу препаратів, до складу яких входять дані речовини, рекомендовано додавати рослинні екстракти

Подяки. Робота виконана за фінансової підтримки Міністерства освіти і науки України (номер державної реєстрації 0119U100551).

\section{References:}

1. Alekseyev F. F., Asriyan M. A., Bel'chenko N. B. (1991) Promyshlennoye ptitsevodstvo [Industrial poultry farming]. M.: Agropromizdat, 544 (in Russian).

2. Bordunova O.H., Chernyavs'ka T.O., Chivanov V.D. (2007). Prohnozuvannya yakosti inkubatsiynykh yayets' [Forecasting the quality of hatching eggs]. Visnyk ahrarnoyinauky, №6, 53-58 (in Ukrainian).

3. Bordunova O. H., Popsuy V.V., Astrakhantseva O.H. (2009). Nanodezinfektant XXI storichchya: fundamental'ni i prykladni aspekty vykorystannya u ptakhivnytstvi [Nanodezinfectant of the XXI century: fundamental and applied aspects of use in poultry farming]. Ptakhivnytstvo: mizhvid. temat. nauk. zb., Vyp. 62, Kharkiv: IP UAAN, 6-8 (in Ukrainian).

4. Il'ina A.V., Kulikov S.N., Chalenko G.I., Gerasimova N.G., Varlamov V.P. (2008). Polucheniye i issledovaniye monosakharidnykh proizvodnykh nizkomolekulyarnogo khitozana [Obtaining and research of monosaccharide derivatives of low molecular weight chitosan]. Prikladnaya Biokhimiyai Mikrobiologiya, T. 44, № 5, 606-614 (in Russian).

5. Karatayev A.M., Sakhatskyy N.Y., Bezrukavaya Y.YU. (2004). Novyy dezynfektant shyrokoho spectra deystvyya [A new broad-spectrum disinfectant]. Ptakhivnytstvo: mizh vid. temat. nauk. zb. Instytut ptakhivnytstva UAAN. Kharkiv, Vyp. 53, 572(in Ukrainian). Russian).

6. Tret'yakova A.D. (1988). Veterinarnyye preparaty: spravochnik [Veterinary drugs: a reference book]. M. :Kolos, 346 (in

7. Brake, J., Walsh, T.J., Benton, C.E. Jr., Petitte, J.N., Meijerhof, R., Peñalva, G. 1997. Egg handling and storage. Poult. Sci. Issue (76). P. 144-151.

8. Cheng M. Visible-light-assisted degradation of dye pollutants over $\mathrm{Fe}(\mathrm{III})$-loaded resin in the presence of $\mathrm{H}_{2} \mathrm{O}_{2}$ at neutral pH values / M. Cheng, Ma J. Li, Y. Huang, J. Zhao [et al.] // Environ. Sci. Technol. - 2004.-38.-P. 1569-1575.

9. Chii Shang. Repression of photoreactivation and dark repair of coliform bacteria by TiO2-modified UV-C disinfection / Chii 
Shang, Lok Man Cheung, Chiu-Man Ho, Minzhen Zeng // Applied Catalysis B: Environmental.- 2009.-V. 89, Issues 3-4.- P.- 536542 .

10. Elmezayyen, A.S. and Reicha, F.M. (2015). Preparation of Chitosan Copper Complexes: Molecular Dynamic Studies of Chitosanand Chitosan Copper Complexes. Open Journal of Applied Sciences, 5, 415-427.

11. Hernandez-Hernandez A. Identification of some active proteins in the process of hen eggshell formation / A. HernandezHernandez, J. Gomez-Morales, A. B. Rodriguez-Navarro, J. Gautron [et al.] // Cryst. Growth Des. - 2008. -V.8.-P.-4330-4339.

12. Herruzo R. Efficacy of a new peracetic acid-based disinfectant agent ('Adaspor® ready to use') / R. Herruzo, M.J. Vizcaino, I. Herruzo // Journal of Hospital Infection, Volume 74, Issue 2, February 2010, Pages 192-193

13. Merianos J. J. (2001). Surface-Active Agents. Disinfection, sterilization and preservation. Ed. by S. S. Block. New York: Lippincott Williams \& Wilkins, 283-321.

14. Russel A. D. (2001) Principles of Antimicrobial activity and resistance. Part II: Fundamental Principles of Activity. Disinfection, sterilization and preservation. Ed. by S.S. Block. New - York: Lippincott Williams \& Wilkins, 31-57.

15. Samuel P. Davis (ed.) (2011). Chitosan: Manufacture, Properties, and Usage. Nova Science Publishers, 507

16. Xian De li (2009). Effect of combination of chitosan coating and irradiation on physicochemical and functional properties of chicken egg during room-temperature storage. Radiation Physics and Chemistry, Vol. 78,Is. 7-8, 589-591.

Petrenko Hanna Oleksandrivna, graduate student,

Bordunova Olga Georgievna, Doctor of Agricultural Sciences, Profesor,

Sumy National Agrarian Unuversity (Sumy, Ukraine)

Study of the effect of chemical-based disinfectants on the eggshell of poultry

The paper presents the results of studying the effect of disinfectants based on chemicals on the structure and properties of poultry eggshells. Disinfectant properties and effects on poultry shells and shells of poultry eggs of preparations based on aldehydecontaining substances, compounds based on hydrogen peroxide and substances based on peracetic acid are considered. The use of disinfectants that do not affect the quality of hatching eggs and have a positive effect on the development of poultry embryos is a topical issue in poultry. Incubatory eggs of white leghorn chickens were used in the work. Eight groups of 144 eggs each were formed for the experiments. Prior to incubation, eggs were treated with solutions of substances and preparations: formaldehyde, glutaraldehyde, metacide, Virkon - S (KRKA, Slovenia), CID - 20 with the addition of peracetic acid (NOC), VIROCID with NOC, CID - 20, NOC and plant extras., VIROCID, NOC and plant extracts. Samples of shells taken after hatching of chickens were analyzed by scanning electron microscopy on the device REMMA-102 immediately after drying the solutions. Treatment of poultry eggs with disinfectants is one of the main requirements for incubation. However, the use of disinfectants with excellent bactericidal and fungicidal properties does not always lead to the desired result. In particular, preparations based on chemicals, such as aldehydecontaining compounds, reduce the protective effect of the cuticle and have carcinogenic properties against staff working in poultry farms. Peroxide-based preparations have toxic effects on developing embryos and destructive activity on the bioceramic layer of the shell. To mitigate the negative effects of drugs that contain these substances, it is recommended to add plant extracts

Key words: technology, breeds, incubation, disinfectants, shell.

Дата надходження до редакції: 03.12.2021 р. 